\title{
The Case of the Missing Indigene: Debate Over a "Second-Generation" Ethnic Policy
}

\section{Citation}

Elliott, Mark. 2015. “The Case of the Missing Indigene: Debate Over a 'Second-Generation' Ethnic Policy." The China Journal 73 (January): 186-213. doi:10.1086/679274.

\section{Published Version}

doi:10.1086/679274

\section{Permanent link}

http://nrs.harvard.edu/urn-3:HUL.InstRepos:34306000

\section{Terms of Use}

This article was downloaded from Harvard University's DASH repository, and is made available under the terms and conditions applicable to Other Posted Material, as set forth at http:// nrs.harvard.edu/urn-3:HUL.InstRepos:dash.current.terms-of-use\#LAA

\section{Share Your Story}

The Harvard community has made this article openly available.

Please share how this access benefits you. Submit a story. 


\title{
The Case of the Missing Indigene: Debate Over a "Second-Generation" Ethnic Policy
}

\author{
Mark Elliott*
}

\begin{abstract}
A B S T R ACT
The last few years have seen a vigorous public policy debate emerge over a "secondgeneration" ethnic policy (dierdai minzu zhengce) which, if implemented, would constitute a major revision of ethnic politics in China. Despite the fact that nationalities policy is a notoriously sensitive subject within China, the debate is happening openly in newspapers, academic journals and on the Internet. The prominence accorded to anthropological theory and international comparison is a notable feature of the debate. This article first explores the main positions in the ongoing policy discussion, then goes on to argue that, rather than comparing China's non-Han peoples to minority immigrant populations in the industrialized democracies, a better comparison is to indigenous peoples. It then considers why this perspective is completely missing from the present debate.
\end{abstract}

$\mathrm{I}_{\mathrm{r}}^{\mathrm{n}}$ n recent years, a debate has arisen among intellectuals and officials in the People's Republic of China over the proper framework for managing the affairs of the country's roughly 114 million citizens who identify themselves ethnically other than as Han Chinese (Hanzu 汉族). ${ }^{1}$ The earliest questioning of the present system for determining minority nationality status (shaoshu minzu chengfen 少数 民族成分) dates from about a decade ago, but the discussion has become greatly amplified since 2008, as the situation in many of the country's ethnically distinct frontier regions-notably, Tibet, Xinjiang and Mongolia-has deteriorated,

* A version of this article was first presented at an international conference on the "second-generation" policy held at Shiga University (Japan) in December 2012. I would like to thank the organizers of that meeting, Borjigin Burensain and Uradyn Bulag, for the invitation to attend, and also to thank participants for their comments. Audiences at subsequent presentations at the Center for Chinese Studies at the University of California, Berkeley, and the Fairbank Center for Chinese Studies, Harvard University, have been similarly generous. Thanks also to Stevan Harrell, Ma Rong, Jian Zhixiang, Elizabeth Perry, Sheena Greitens, Blaine Gaustad and the anonymous reviewers for The China Journal for discussions on this topic and for helpful suggestions on earlier drafts, which have saved me from many mistakes. Responsibility for remaining errors lies with me.

1. "Renkou pucha: Hanzu renkou zhan $91.51 \%$, shaoshu minzu renkou zhan $8.49 \%$ " (Population Census: Han Population 91.51\%, Minority Population 8.49\%) (28 April 2011), http://www.china.com.cn/news/2011 -04/28/content_22458103.htm, accessed 22 August 2014. If we use figures from the 2010 census, which show a total population of 1,339,724,852 (excluding Hong Kong, Macao and Taiwan), 8.49 per cent works out to $113,742,640$.

The China Journal, no. 73. 1324-9347/2015/7301-0008. Copyright 2015 by The Australian National University. All rights reserved. 
a fact widely acknowledged even within China. In response to a perceived need for more effective means to deal with the problem of ethnic unrest, some scholars have begun to moot alternative models for restructuring ethnic policy in the PRC.

Most prominent among these scholars is the Peking University sociologist, Ma Rong (马戎), who advocates the elimination of minority nationality status. In its place, Ma favors a model of ethnic assimilation which he derives from studying the experience of countries in the West, principally the United States. In promoting this idea, and in rejecting the term minzu (民族) in favor of zuqun (族群), Ma's stated goal is to "de-politicize" (qu zhengzhihua 去政治化) ethnic identity, thereby reducing anxiety over the implications, territorial and otherwise, of the continued difficulties experienced by leaders at local and central levels in the administration of non-Han areas.

Ma, who is himself a Hui, believes that such a policy would lead to a more stable social outcome, with Han and non-Han alike assimilated into a single nation constituted, not of Han, Manchus, Mongols, Muslims, Tibetans, Zhuang, Yi and so forth, but of an indivisible "Chinese people", consolidated under the name Zhonghua minzu (中华民族). ${ }^{2}$ The underlying idea is to create a community of citizens bound together in a shared political enterprise and to short-circuit the divisive forces behind ethnic interest groups. Ma argues that, for this to occur, a significant strengthening of China's legal system is necessary; this would ensure improved levels of social justice and ethnic equality sufficient to allow satisfactory guarantees of protection of cultural freedoms promised by the state. According to $\mathrm{Ma}$, the present patchwork of peoples is vulnerable to conflict that may lead to the disintegration of the state. Potential "national independence movements", he says, are the greatest threat that China faces in the $21^{\text {st }}$ century. ${ }^{3}$ Ma sees the adoption of the Soviet model as the root of present problems, but he has been criticized for praising the norms of Western liberal pluralism and failing to mention debates over "multiculturalism" and other issues that continue to provoke widespread concern, and occasional violence, even in societies committed to toleration of non-majority groups.

2. Ma Rong, "Lijie minzu guanxi de xin silu: shaoshu zuqun wenti de 'qu zhengzhihua”" (A New Approach to Understanding Minority Group Relations: The "Depoliticization" of the Ethnic Question), Beijing daxue xuebao (Journal of Peking University), No. 6 (2004), pp. 122-33; and Ma Rong, "A New Perspective in Guiding Ethnic Relations in the $21^{\text {st }}$ Century: 'De-politicization' of Ethnicity in China”, Asian Ethnicity, Vol. 8, No. 3 (October 2007), pp. 199-217.

3. Ma Rong, "Ruhe renshi 'minzu' he 'Zhonghua minzu': huigu 1939-nian guanyu 'Zhonghua minzu shi yige' de taolun" (On Differentiating Minzu and Zhonghua Minzu: A Look Back at the 1939 Debate on "The Chinese People Are One"), Zhongnan minzu daxue xuebao (Journal of South-Central University of Nationalities), Vol. 5 (2012), pp. 4-5, and Ma Rong, "Ershi shiji de Zhongguo shifou cunzai guojia fenlie de fengxian?" (Does There Exist the Risk of National Break-Up in 21 $1^{\text {st }}$-Century China?), Minzu shehuixue yanjiu tongxun (Bulletin of Ethnic Sociology), Vol. 75 (November 2010), p. 2. 
It is hard to disagree with Ma Rong's critique that current ethnic policy in the PRC is gravely deficient in many ways. After the eruption of serious violence in Tibet in 2008 (the so-called "3-14 incident") and in Xinjiang in 2009 (the "7-15 incident"), scarcely a month goes by without new evidence of deepening discontent somewhere in China's Inner Asian frontiers. Beginning in 2011, self-immolations became widespread in Tibetan regions, and have continued throughout 2014, numbering 125 at last count. ${ }^{4}$ Summer 2011 saw violence in Inner Mongolia in protest over Han disregard for ecological despoliation and land rights, leading to a lockdown of university campuses and a disruption of provincial communications for some days. Alleged hijackings and other incidents in Khotan and elsewhere in the summer of 2012 turned out to be harbingers of even more serious unrest in 2013 and 2014, with multiple incidents (bombings, shootings, knife attacks) occurring both in Xinjiang itself—not just Ürümchi, but Aksu, Kashgar, Yarkand, Khotan and elsewhere in the Tarim Basin-as well as in other locations around the country, including Beijing and Kunming (the "3-01 incident"). ${ }^{5}$

In all these cases, the official position of the government is that the primary source of these troubles lies with the activities of separatist elements and religious extremists, not with any structural flaws in policy. All the same, given a clearly worsening situation, even loyal government spokesmen are finding it hard to claim that harmony reigns among all of China's 55 recognized minority groups. The Party's unofficial English-language organ, Global Times (Huanqiu shibao 环球时报), admitted in February 2012: “It is true that in recent years, Tibet and Xinjiang have not been as peaceful as before". ${ }^{6}$ Others are more explicit:

It goes without saying that in the course of implementing all kinds of policy, questions arise to varying degrees, such as in scaling up a policy or in poor implementation ... We cannot disguise the fact that there have been flaws in the ways policies have been carried out. ${ }^{7}$

4. Figures from the International Campaign for Tibet, http://www.savetibet.org/resources/fact-sheets/self -immolations-by-tibetans/, accessed 28 July 2014.

5. A car was set ablaze, and crashed into the sidewalk at Tiananmen Square in October 2013, killing five, while a mass knife attack at the Kunming train station in March 2014 left 29 civilians dead, plus the perpetrators. A bomb that exploded in a morning market in Ürümqi in May 2014 killed 31 and injured another 94 . Summer 2014 saw additional serious violence across the region that left scores dead. In these and all other incidents, it is practically impossible to identify the assailants or their motives with any confidence.

6. Qian Zhang, "No Need to Sweat Over Minor Unrest", Global Times (2 February 2012), available at http://www.globaltimes.cn/content/694239.shtml, accessed 19 August 2014.

7. Hao Shiyuan, "Jianchi minzu quyu zizhi zhidu bixu wanshan minzu zhengce" (In Order to Hold Firmly to the System of Ethnic Autonomous Regions, Ethnic Policies Must Be Improved), Chuancheng, Vol. 5 (2011), pp. 64-66. 
The question has become: what to do about it? Indeed, this was the very question posed in a featured story that appeared on the influential Caixin (财新) website in March 2014. ${ }^{8}$ So far, however, no one seems to have a clear answer.

This article explores the current debate among scholars and Party officials over potential revisions to China's policies on ethnic minorities, a debate that has taken place, not just in government meeting rooms and conferences, but also in the pages of academic journals and Party publications, as well as on the Internet. While it is not unprecedented for such sensitive topics to be discussed so openly, one interesting dimension is the degree to which Western anthropological theory has shaped the debate. ${ }^{9}$

\section{A TURNING POINT IN ETHNIC POLICY?}

The basic choice as to what to do about current ethnic policies is simple: either present policies are continued, but with efforts made to improve implementation, or present policies are modified (or abandoned altogether) and a new order created to solve the problem of ethnic conflict by eliminating official recognition of ethnic difference as such.

One version of a proposed new order is the pluralist model advocated by $\mathrm{Ma}$ Rong, already outlined above, which has so far failed to gain much popular support. Even if they sympathize with Ma's unfavorable assessment of the country's ethnic situation and his hopes for a more pluralistic approach to ethnic issues, many scholars oppose both his theoretical premises and his suggestions for policy reform. One vigorous line of criticism has come from Zhang Haiyang (张海洋), professor at Minzu University of China (Zhongyang minzu daxue 中央民族大学). Zhang wholly rejects Ma's ideas for reorganizing the basics of ethnic policy-not because they are wrong (Zhang does not even discuss the idea of "depoliticization" on its merits) but because, he says, it is unacceptable for intellectuals to question the status quo:

8. Yang Baolu and Qin Xudong, "Ma Rong: Zhongguo minzu zhengce yingzuo zhongda tiaozheng" (Ma Rong: A Major Adjustment Should Be Made to China’s Ethnic Policies), Caixin wang (23 March 2014), http:// china.caixin.com/2014-03-23/100655305.html, accessed 21 August 2014. This story was followed by a lengthy opinion piece by Ma Rong, in which he refers to the present moment as a "transitional period" (zhuanxing shiqi) and details his concerns over a continuing hard line. See Ma Rong, "Zhuanxing shiqi de zuqun guanxi" (Ethnic Relations in a Time of Transition), Caixin wang (25 March 2014), http://opinion.caixin.com/2014-03 -25/100656166.html, accessed 23 July 2014.

9. Valuable reviews of the policies discussed in this article may be found in Barry Sautman, "Scaling Back Minority Rights? The Debate About China's Ethnic Policies", Stanford Journal of International Law, Vol. 46 (Summer 2010), pp. 1-90, and James Leibold, Ethnic Policy in China: Is Reform Inevitable? (Honolulu: EastWest Center, 2013). 
The duty of Chinese scholars is not to guide the national society in how to fix fundamental national conditions and allow minorities to be reborn, but [to guide society] in how better to comprehend national conditions and, on the basis of those conditions, to protect and perfect the country's laws and social systems in order to manifest the national will. ${ }^{10}$

In other words, Zhang appears to be saying that, in doing their research, scholars must keep the interests of the state uppermost in mind. This may represent the viewpoint of some academics today, though what proportion would be hard to say. It is also possible, and perhaps more likely, that Zhang-a Manchu, and a person not known to shy away from expressing strong opinions himself (he has pressed publicly for the implementation of true autonomy in ethnic autonomous zones ${ }^{11}$ ) - is simply using this as a blunt instrument to dull Ma's critique.

Others opposing Ma Rong are scholars who (like Zhang) are themselves of minority background, and who fear that the dismantling of the structures of ethnic identity that have been carefully nourished over several decades (with the glaring interruption of the Cultural Revolution, of course) would be the beginning of the end for non-Han identity and culture in China. Removing even the modest protections offered for native culture and religion that presently exist would leave people even more vulnerable to Han-led domination than is already the case. This view is mostly expressed informally in conversations off the record, but one critique that refers explicitly to the failure of Chinese scholars to appreciate the native position is that by Fudan's Naran Bilik (纳日碧力戈). ${ }^{12}$ Moreover, scholars outside China, such as Barry Sautman and James Leibold, express concern that doing away with the present ethnic regime would lead to significant instability in many parts of the country. ${ }^{13}$

10. Zhang Haiyang, "Hanyu 'minzu' de yujing zhongxing yu pi-ge-ma-li-weng xiaoying: Ma Rong jiaoshou '21 shiji de Zhongguo shifou cunzai guojia fenlie de fengxian' shuping”' (The Discursive Neutrality of the Word Minzu in Chinese and the Pygmalion Effect: An Analysis of Professor Ma Rong's "Does There Exist the Risk of National Break-up in 21 $1^{\text {st }}$ Century China?"), Sixiang zhanxian (Ideological Front), Vol. 37, No. 4 (2011), pp. 17-19.

11. See Zhang Haiyang, "Zhonghua minzu daole jiangxin xiumu de shihou: jian lun minzu quyu zizhi zuowei 'quanli zhi long' jihuan chongjizhi" (The Chinese People Have Arrived at a Time to Talk Openly and Constructively: With a Discussion of the Ethnic Autonomous Zones as "Frameworks to Limit Authority" and Mechanisms for Buffering the Crisis), originally posted 8 April 2013, available at http://blog.sina.com.cn/s /blog_48c6994f0101cc6t.html, accessed 30 July 2014.

12. See Barry Sautman, "Scaling Back Minority Rights?", pp. 80-81, and "Paved with Good Intentions: Proposals to Curb Minority Rights and Their Consequences for China”, Modern China, Vol. 38 (2012), p. 20; also Naran Bilik [Na-ri Bi-li-ge], "Quanqiuhua shiyexia de Zhongguo minzu guanxi yanjiu: neishi, zijue, yu zhengyi” (Ethnic Relations in China under Globalization: Reflexivity, Self-Consciousness and Justice), Zhongguo minzu daxue xuebao (Journal of the Central University for Nationalities), Vol. 38, No. 6 (2011), pp. 5-13.

13. See Barry Sautman, "Scaling Back Minority Rights?" and "Paved with Good Intentions", and "An India/ US Model for China's Ethnic Policies: Is the Cure Worse than the Disease?”, East Asia Law Review, Vol. 9, 
For very different reasons, a majority of Party spokesmen also seem to agree that a fundamental shift in ethnic policies is not a good idea. A representative voice is that of Hao Shiyuan (郝时远), an ethnic Mongol who is the Deputy Secretary General of the Chinese Academy of Social Sciences. At an October 2010 meeting with Chinese and foreign journalists, Hao noted:

The system of autonomous rule over ethnic minority areas is one of the nation's fundamental political systems, and represents the institutional mechanism for handling and resolving ethnic issues. In the 60 years that the ethnic autonomy system has been in effect, it has served in important ways to guarantee the equal rights of China's ethnic minorities, promoted the economic and social development of ethnic minority areas, and protected the unity and integrity of national territory. ${ }^{14}$

The next year, in a veiled criticism of Ma Rong and others, Hao went further:

In studying and assessing the system of minority autonomous regions and ethnic policy structures in our country, we must first focus on how ethnic policies are being implemented, and to what degree they are being carried out, not question the intention behind the formulation of those policies. ${ }^{15}$

The opposition here, and the deep skepticism expressed in many of the articles that have appeared addressing Ma's proposal, would appear to have doomed Ma's critique to irrelevance. In its 2010 annual review of current political thinking, the United Front Work Department (Tongzhanbu 统战部) of the CCP devoted one chapter to the question of ethnic relations. The summary of Ma's argument there is neutral, but there is no mistaking the disapproving attitude of the editors, who cite the objections raised by Ma's critics that an "apolitical" approach to ethnicity is unsuited to Chinese historical and social realities. ${ }^{16}$ Thus, the initial mainstream response to Ma Rong's proposal has seemed to be that changing the present ethnic order is out of the question.

No. 3 (forthcoming). See also James Leibold, "Toward a Second Generation of Ethnic Policies”, China Brief, Vol. 12, No. 13 (July 2012), http://www.jamestown.org/, accessed 31 July 2014; and Elena Barabantseva, Overseas Chinese, Ethnic Minorities and Nationalism: De-Centering China (New York: Routledge, 2011), pp. 95-96. Leibold has more recently written that the adoption of DMZ ("Second-Generation Ethnic Policy", di'erdai minzu zhengce) policies "would likely require the collapse of the CPC (sic) and China's existing political system" (James Leibold, Ethnic Policy in China, p. 51).

14. Wang Yiyin, "Minzuxuejia Hao Shiyuan chanshi minzu quyu zizhi zhidu" (Ethnologist Hao Shiyuan Explicates the System of Minority Nationality Autonomous Regions), Guangming ribao (Guangming Daily) (15 October 2010), http://www.mzb.com.cn/html/node/146945-1.htm, accessed 19 November 2012.

15. Hao Shiyuan, "Jianchi minzu quyu zizhi zhidu", p. 66.

16. Lin Shangli and Xiao Cunliang (eds), Tongyi zhanxian lilun yu shijian qianyan: 2010 nian (The Theory of the United Front and the Leading Edge of Practice: 2010) (Shanghai: Fudan University Press, 2010), pp. 151-52. 
Subsequently, however, significant voices dissenting from this view have come forward to support the idea of reformulating ethnic policy, if on very different grounds. Foremost among these are Hu Angang (胡鞍钢) and Hu Lianhe (胡联合), researchers at the "Center for China Study" (Guoqing yanjiu zhongxin 国情研究中心, perhaps more appropriately translated as the "Center for the Study of Unique National Conditions" ${ }^{17}$ ) at Tsinghua University, which $\mathrm{Hu}$ Angang founded in 1999 and has directed ever since. Joining the debate in September 2011, they referred to the discussion at a January 2010 conference on Tibet and Xinjiang, during which it was observed that in ethnic relations there was a need to move from “interaction" (jiaowang 交往) and “interchange" (jiaoliu 交流) to “intermingling” (or integration, jiaorong 交融). ${ }^{18}$ This formulation一what one might, in keeping with Party style, call the "three inters" (sanjiao 三交)—surfaces repeatedly in this analysis:

How can we urge all the minzu in the country to become more active in contact, to exchange more deeply, and to mix more self-consciously so as to fuse into a single "Chinese people" (Zhonghua minzu 中华民族)? With our attention firmly fixed on the strategic structures of the nation's long-term security, and with a broad international perspective, we must fully recognize the special importance of advancing ethnic contact, exchange and integration. We must promote ethnic contact, exchange and integration in a way that keeps up with the times and guarantees that the amalgamation of the Chinese people will win steady reinforcement and great development. ${ }^{19}$

Implicit here is the idea, which they share with Ma Rong, that much has changed since 1979 (not to mention since 1949), and that policies need to be reconsidered. To a new set of policies that would do away with the current minority nationality system, they gave the name "Second-Generation Ethnic Policy" (di'erdai minzu zhengce 第二代民族政策, hereafter DMZ), a term meant to highlight the abandonment of what in hindsight must be considered the "First-Generation Ethnic Policy" adopted in the 1950s, ostensibly on the Soviet model..$^{20}$

17. I adopt this translation from that of Geremie Barmé; see "Telling Chinese Stories", at the China Story website, http://www.thechinastory.org/yearbook/telling-chinese-stories/, accessed 30 July 2014.

18. Hu Angang and Hu Lianhe, "Di'erdai minzu zhengce: cujin minzu jiaorong yiti he fanrong yiti" (A Second-Generation Ethnic Policy: Advancing a Single Body of Ethnic Integration and Prosperity), Xinjiang shifan daxue xuebao (Journal of Xinjiang Normal University), Vol. 35, No. 5 (September 2011), p. 1.

19. Hu Angang and Hu Lianhe, "Di'erdai minzu zhengce", p. 1.

20. Hu Angang and Hu Lianhe do not explain their choice of the phrase "second-generation", which obviously does not mesh with the generations of leadership in the PRC (the group now in power in China is commonly referred to as the fifth generation). One may speculate that $\mathrm{Hu}$ and $\mathrm{Hu}$ are counting the passage of 60 years since the founding of the PRC as marking the end of one "generation" (jiazi) and the start of the next. 
The article by $\mathrm{Hu}$ Angang and $\mathrm{Hu}$ Lianhe expounds on the importance of strengthening "the people", using an unusual (and controversial) term, guozu (国族), rarely seen after the Republican era. ${ }^{21}$ This usage reveals the authors' profound fear of the consequences of the lack of a strong national identity (along with their profound misunderstanding of the rise of the nation-state in Europe, based on the assumption that coherent national identities formed the leading edge of this process - for which their main authority seems to be a 2008 Chinese translation of Harold Isaacs' Power and Identity: Tribalism in World Politics [1979]). It also demonstrates all too clearly the terminological dead-end in which even careful writers find themselves in when it comes to minzu. As they point out:

Without doubt, every modern state must construct an identity between the people and the nation; without such an identity, the outer shell of the state's institutions will invariably be unstable, and the state will find it hard to control the people effectively. In fact, one should clearly recognize that, from the point of view of state control, the maintenance of long-term order in any country is rooted in the institutional establishment of a single, unified people (minzu, guozu), and in strengthening that identity while weakening particular ethnic identities (zuqun, minzu). Through institutional arrangements, [one can] bring about the depoliticization of ethnic problems and deny any opportunities to anyone to claim to represent or to lead "local ethnic interests".22

Two points in particular stand out here-the role of the state as the prime mover in identity construction, and the fear of surging and uncontrollable "local interests" - that clearly form the core of the Hus' concerns.

Ma Rong and the two Hus share the belief that China's future depends upon the realization, in practice and not just in rhetoric, of the idea of the Zhonghua

\footnotetext{
21. Guozu was understood by Sun Yatsen as a "single, organic, and indivisible race-state" (James Leibold, Reconfiguring Chinese Nationalism: How the Qing Frontier and Its Indigenes Became Chinese [New York: Palgrave Macmillan, 2007], p. 149). Zhang Haiyang argues that the term guozu is just another way of talking about a single nationality, overwhelmingly Han-dominated, into which all minority peoples would be assimilated (Zhang Haiyang, "Zhonghua minzu daole jiangxin xiumu de shihou"). The term was dissected and critiqued forcefully along these same lines in an article in Nanfang zhoumo (Southern Weekly); see Ming Hao, "Buying zaijiang guozu" (We Should Not Again Be Using the Word Guozu), Infzm (Southern Weekly Online), originally posted 23 November 2012, http://www.infzm.com/content/83085, accessed 30 July 2014. Most recently, Naran Bilik has offered a sophisticated analysis of the term; see Naran Bilik, "Yimin fushi he yishi zhengming: Zhongguo minzu wenti de 'feiwenti chuli'" (Using Names to Supplement Reality and Using Reality to Correct Names: The "It's-Not-a-Problem Handling" of China's Ethnic Problems), Tansuo yu zhengming (Exploration and Contending), Vol. 3 (2014), pp. 35-36. Zhu Lun, a specialist on ethnic studies at CASS, has also criticized the reappearance of this term, behind which lies, he believes, thinking that contributes both to "splittism" and to "assimilationism". See Peng Binbin, "Re huati yu leng sikao" (Cold Thinking and a Hot Topic), Dangdai shijie yu shehui zhuyi (Contemporary World and Socialism) (October 2013), p. 5.

22. Hu Angang and Hu Lianhe, "Di’erdai minzu zhengce", pp. 2-3.
} 
minzu. Both Ma Rong's platform for policy change and that embodied in the DMZ embrace the idea of eliminating the ethnic identity categories that presently exist; Ma's recourse to the notion of the "melting pot" (daronglu 大熔炉, lit. "big melting furnace") as a metaphor for ethnic processes in American society signals his hope that eventually ethnicity will cease to be much of an issue. He has said as much openly in interviews. ${ }^{23}$ Other participants in the DMZ debate have also seized upon this idea as a good model for China: much better the US "melting pot" than the Soviet (or Yugoslav) "hors doeuvres platter" (minzu dapinpan 民族大拼盘), ${ }^{24}$ but $\mathrm{Ma}$ is sufficiently realistic to know that this outcome, if it ever eventuates, will take place in some distant future. In the meantime, as he has reminded critics, "I have never called for abandoning preferential policies immediately, but for an evaluation of present policies and for necessary adjustments in light of the real outcomes of these policies". ${ }^{25}$

The principal difference is that, whereas Ma favors policies that would penalize anti-minority prejudice and accord considerably more cultural and political room for non-Han groups (with the idea that, over time, they would come of their own accord to identify with the Zhonghua minzu), $\mathrm{Hu}$ and $\mathrm{Hu}$ promote instead the idea of rapid assimilation of the non-Han into the Zhonghua minzu—that is, the Han. For them-though pointedly not for $\mathrm{Ma}$, who is at pains to distinguish his ideas from those of "second-generation" advocates, and who is arguably much more interested in creating a kind of civil unity that can accommodate ethnic diversity in the short- to middle-term ${ }^{26}$-this depends on eradicating the specific differences that divide the minority shaoshu minzu (少数民族) from the majority duoshu minzu (多数民族), and particular shaoshu minzu from each other.

How is this to happen? Hu and Hu provide an answer that is straightforward enough: the "fusion" or "blending" (jiaorong) that is the purported endpoint of ethnic policy in Tibet and Xinjiang (and, presumably, everywhere else, too), and which, they argue, will lead to the welding together of all peoples within China into a single Zhonghua minzu (or, in some cases, as seen above, guozu), means that, in effect, everyone will become Han: "The Han people, who form the majority among the Zhonghua minzu, have always been a very inclusive people, and have incorporated many other peoples who did not originally belong to the

23. Ma Rong and Zou Zan, "Quanqiu hua, bentuxing, yu dangdai xifang minzu zhuyi lilun: Beijing daxue boshisheng daoshi Ma Rong jiaoshou fangtan" (Globalization, the Home-Grown, and Contemporary Western Theory on Nationalism: An Interview with Peking University Professor Ma Rong), Shehui kexuejia (Social Scientists), Vol. 4 (2011), p. 8.

24. Hu Lianhe and Hu Angang, "'Minzu da ronglu' he 'minzu da pinpan': guowai minzu zhengce de liangda moshi" (The "Melting Pot" and the "Hors d'Oeuvre Platter": Two Grand Models of Overseas Ethnic Policies), Zhongguo shehui kexue bao (Chinese Social Sciences Today), Vol. 231 (20 October 2011), p. 7. Instead of "hors d'oeuvres platter", some formulations have "salad bowl" (shala wan) or "mosaic" (masaike).

25. Ma Rong, "Zhuanxing shiqi", p. 241.

26. Ma Rong, "Zhuanxing shiqi". 
Han". ${ }^{27}$ They pursue this idea explicitly in a 2013 article with the provocative title, "The Bedrock of the Chinese Dream Is the Integration of the Peoples of China into a Single Nation-Race" (Zhongguomeng de jishi shi Zhonghua minzu de guozu yitihua 中国梦的基石是中华民族的国族一体化). ${ }^{28}$ This, of course, is precisely what non-Han in China today fear most: their own disappearance. ${ }^{29}$ It is quite different, too, from what Ma Rong has proposed. It is as if the clock were turned back 70 years to the assimilationist logic presented in Chiang Kai-shek's famous discussion of these issues in China's Destiny, in which he described all of the country's non-Han peoples as having originally been "branches" of the Han, and urged that they should be quickly reintegrated. ${ }^{30}$ Ironically, it was recognition of the ethnic chauvinism inherent in this argument that enabled the CCP to win the crucial support of non-Han groups in the frontiers during the pre-1949 period. ${ }^{31}$ It is thus no wonder that talk of a DMZ has raised concerns among ethnic minorities and Party cadres alike. At stake is not just national unity but Party orthodoxy, since the debate opens up the old question of the connection between "ethnic struggle" and "class struggle". ${ }^{32}$

In this connection, one might note the storm unleashed when Zhu Weiqun (朱维群), executive vice director of the Party's United Front Work Department, came out publicly in favor of some version of a DMZ in January 2011. Adopting a position somewhere between Ma and the two Hus, Zhu cautioned against imposing "bureaucratic measures to forcefully promote ethnic fusion", but at the same time allowed that "building fusion on a conscious, voluntary foundation should be permitted". In his view, "fusion" was not to be confused with "assimilation" or "sinification", but was rather the creation of a happy, pluralistic combination-the

27. Hu Angang and Hu Lianhe, "Dỉerdai minzu zhengce", p. 3.

28. Hu Angang and Hu Lianhe, "Zhongguomeng de jishi shi Zhonghua minzu de guozu yitihua" (The Bedrock of the Chinese Dream Is the Integration of the Peoples of China into a Single Nation-Race), Qinghua daxue xuebao (Journal of Tsinghua University), Vol. 28, No. 4 (2013), pp. 111-16, 160. The English title given by the authors to their article is particularly worth citing here: "China Dream: It Belongs to Everyone of the Chinese Nation".

29. Powerful expressions of this fear, addressed specifically to the DMZ policy, is found in Dawa Wangchen [Da-wa Wang-qian], "Xiaomie Xizang wenhua shi suowei di'erdai minzu zhengce de zuizhong" (The Ultimate Goal of the So-Called Second-Generation Ethnic Policy Is the Annihilation of Tibetan Culture), originally posted on Tibet.net (9 July 2012), http://xizang-zhiye.org/2012-07-09-11-39-47/, accessed 30 July 2014; and Altanggerel (A-la-teng-ge-ri-le), “'Di’erdai minzu zhengce’ de shizhi shi shitu tonghua, xiaomie shaoshu minzu" (The Real Nature of the "Second-Generation Ethnic Policy" Is the Attempt to Assimilate and Exterminate Ethnic Minorities), Menggu xinwen (Mongolia News) (21 September 2013), http://mongoliinmedee1.blogspot.com/2013/09/blog-post_8538.html, accessed 30 July 2014.

30. Chiang Kai-shek, China's Destiny (New York: Macmillan, 1947). For a full discussion of this text, see James Leibold, Reconfiguring Chinese Nationalism.

31. See Xiaoyuan Liu, Frontier Passages: Ethnopolitics and the Rise of Chinese Communism, 1921-1945 (Stanford: Woodrow Wilson Center Press; Stanford University Press, 2004).

32. See "Dangqian woguo guonei minzu wenti he jieji douzheng" (Contemporary Domestic Ethnic Issues and Class Struggle), Hongqi (Red Flag) (2 July 1964), at http://blog.sina.com.cn/s/blog_8827a0190101g7ou .html, accessed 30 July 2014. 
best of both worlds, so to speak. ${ }^{33}$ Significantly, Zhu acknowledged that much has changed since the period of the country's founding and that ethnic policies deserve to be reviewed, leaving the door open to future discussions of amending existing policy: "Therefore we must consolidate 60 years of experience, and especially new social realities, to move forward with the times and perfect and augment these systems". ${ }^{34}$

A year later, Zhu pursued the matter a little further. Repeating his opposition to ending the system of autonomous regions or to moving towards some kind of a federal system ("pernicious" ideas which, he said, were "mostly coming from powers on the outside, but also heard [from some] on the inside" and which had to be "resolutely opposed" ${ }^{35}$ ), he surprised some by stating his belief that it might be time to do away with ethnic status as an official element of citizenship in the PRC:

I personally tend to lean towards removing ethnic classifications from resident IDs, not creating any more minority-governed autonomous regions or cities, and promoting schools where ethnicities mix. In terms both of ethnic development and progress, and of strengthening the unity of the greater Chinese race, it will be necessary to pay close attention to promoting the spread of a common national language and writing system. ${ }^{36}$

This suggestion, that steps be taken toward de-emphasizing the government's commitment to maintaining the status quo on ethnic policy, was the first such statement by a high-ranking member of the leadership and, even though phrased as his personal opinion, attracted much attention. Zhu's additional observation, that non-Han must be made to substitute Chinese for their own native languages, seemed to signal a harder line on the sensitive issue of control over education policies within the autonomous zones.

The question of reforms to nationality policy had in fact earlier been taken up in July 2009 by Guangdong Party chief Wang Yang (汪洋), immediately after the unrest in Ürümqi. At that time, Wang was reported to have alluded to the need to "change with the times", in response to a question from a reporter from Kyōdo News Agency. Affirming the correctness of policies to date, Wang added:

33. Zhu Weiqun, "Guanyu dangqian minzu gongzuo jige wenti de sikao", Zhongguo tongyi zhanxian (United Front Journal), Vol. 1 (2011), pp. 14-17.

34. Zhu Weiqun, "Guanyu dangqian", p. 16.

35. Zhu Weiqun, "Guanyu dangqian”, p. 16.

36. Zhu Weiqun, "Dui dangqian minzu lingyu wenti de jidian sikao" (A Few Thoughts on Current Problems in the Ethnic Area), Xuexi shibao (Study Times) (13 February 2012). The translation here is taken in part from the abridged version of the original article made by China Policy and available at its website, http:// www.chinapolicycn.com. 
Of course, in a philosophical sense, everything we use is relative, not absolute. Speaking in terms of the continued development of ethnic relations, any given policy must follow in accordance with the changing era and be adjusted and improved. This principle applies not only to ethnic policies, but to nearly all other policies as well. ${ }^{37}$

The intimation here of the possibility of structural reform, not just in ethnic policy, but also across the board, reinforced Wang's reputation (at least then) as one of the more reform-minded of China's top leaders. The question remains, however: what sort of reform?

Many people, Han and non-Han alike, are dissatisfied with current arrangements, of which the shortcomings are plain to see. The desire for change is understandable, but many urge caution until the specifics of such change are spelled out. Such is the message behind some of the pointed responses called forth by Zhu's February 2012 article in Xuexi shibao (Study Times 学习时报), the newspaper of the Central Party School. Consider these remarks by Xiong Kunxin (熊坤新), a professor at Minzu University of China, published in an op-ed in Huanqiu shibao:

There are some scholars who themselves do not engage in research on ethnic theory but who take advantage of their special status and position to call for the "depoliticization" or the "apoliticization" of ethnic questions and who propose instituting a "Second-Generation Ethnic Policy", so as to "institutionally encourage inter-ethnic marriage" and promote the "fusion into a single body" of all minzu on political, economic, cultural and social fronts. I believe that, given the long-term existence of classes, nations and political parties, to want to "depoliticize" ethnic questions is pie-in-the-sky thinking ... The attempt to undertake a critique that would upend the ethnic theory and policies currently in effect in the country, even at the cost of turning it into an approach that reinvents the wheel, is unquestionably to play with fire. If this indeed is how things go, we truly will end up following in the footsteps of the Soviet Union. ${ }^{38}$

This was not polite scholarly disagreement, but an urgent warning-not only about the risks involved in experimenting with policy on such a scale, but about

37. Voice of America, "Wang Yang tan Zhongguo de minzu zhengce wenti" (Wang Yang Discusses China's Ethnic Problems) (31 July 2009), http://www.voachinese.com/content/a-21-2009-07-31-voa41 $-60881482 / 1013610 . h t m l$, accessed 27 June 2012. The story was also reported by James Pomfret via Reuters Reference, but does not appear to have been circulated within Chinese media.

38. Xiong Kunxin, "Jiejue minzu wenti jibude" (There Is No Need to Rush to Solve Ethnic Problems), Huanqiu shibao (Global Times) (18 February 2012). It is not clear whether Xiong's remarks were directed at $\mathrm{Zhu}$, or at Ma and the two Hus. 
the risks involved in permitting scholars not qualified to talk about theory to engage in public debate on the topic.

The debate continued to develop in 2013 and 2014, as tensions in Tibet and especially in Xinjiang continued to build, with more than 100 articles appearing in academic journals and publications of various sorts. ${ }^{39} \mathrm{~A}$ much-publicized exchange of views took place in July-September 2013, in the pages of Huanqiu shibao, between Ma Rong and Huang Zhu (黄铸), head of the research division of the United Front Work Department in which Huang rejected any need to "learn from America", claiming that China's ethnic policies were "among the best in the world" ${ }^{40}$ In an article published elsewhere at the same time, Huang also directly accused Ma Rong of holding views that were anti-Communist. ${ }^{41}$ Little new ground was broken at this time, and the outcome of the $18^{\text {th }}$ Party Congress in November 2013-reaffirming the correctness of current policies on ethnic autonomy-seemed to suggest that change was remote, despite the talk of reform of one sort or another and the growing acknowledgement that ethnic problems were worsening. ${ }^{42}$ However, those supporting some version of a secondgeneration shift must have been encouraged by the remarks made by President Xi Jinping at a work conference in Xinjiang in May 2014. After a tumultuous spring of unprecedented violence by, and against, Uyghurs, Xi said:

Xinjiang's greatest long-range problem remains that of ethnic unity. The more the forces of ethnic separatism attempt to destroy ethnic unity, the more we must strengthen that unity and secure the common defense by the peoples of all ethnicities of the unity of the fatherland, of ethnic unity and of the steel Great Wall of social stability. We must unwaveringly hold fast to the Party's ethnic policies and maintain the system of ethnic autonomous zones. Ethnic unity is the lifeline of all the nation's peoples. We must hold high the banner of ethnic unity, and firmly instill in all ethnic groups consciousness of the nation (guojia), of the citizenry

39. Figure derived from complete text search in the CNKI academic journals database, gb.oversea.cnki .net, accessed 30 July 2014.

40. Huang Zhu, "Zhongguo de minzu zhengce yongbuzhao xue Meiguo" (China’s Ethnic Policies Need Not Follow the US), Huanqiu shibao (7 September 2013), http://opinion.huanqiu.com/opinion_world/2013 -09/4332499.html, accessed 30 July 2014.

41. "Put simply, in wanting to strengthen the 'political identity' of the Zhonghua minzu, Professor Ma Rong is repudiating (fouren) the structures of ethnic identity for the 56 ethnic groups in the country, and is repudiating political belief in Communism and Socialism-with-Chinese-characteristics, along with its political path". See Huang Zhu, "Zhonghua minzu yinggai jianchi hezhong zhengzhi rentong: yu Ma Rong jiaoshou shangque" (What Sort of Ethnic Identity Should the Chinese People Hold on to? A Discussion with Professor Ma Rong), Zhongguo minzubao (China Ethnic News) (6 September 2013), http://www.mzb.com.cn /html/Home/report/439742-1.htm, accessed 30 July 2014.

42. See Yang Renhou, "Zhonggong shibada jianchi he wanshan minzu quyu zizhi zhidu sixiang yanjiu” (Investigation of the Thinking Behind the Decision at the $18^{\text {th }}$ Party Congress to Maintain and Perfect the System of Ethnic Autonomous Regions), Guizhou shifan daxue xuebao (Journal of Guizhou Normal University), Vol. 187 (February 2014), pp. 51-55. 
and of the community of the Zhonghua minzu; to the greatest extent possible, we must unite and rely upon the masses of all ethnicities to have every group, every citizen contribute their strength to the realization of the China Dream of the Great Revival of the Chinese Nation and share in the fruits of the prosperous development of the nation. All ethnic groups should show mutual understanding, respect, tolerance and appreciation, and should learn from and help one other, so that, like the seeds of a pomegranate, they are bound closely together. We must strengthen the interaction, interchange and intermingling between ethnic groups; we must prepare and expand all kinds of shared constructive projects, advance "bilingual education", and promote the building of social structures and community environments in which the people of different ethnic groups are mutually embedded (xianghu qianru 相互嵌入). We must also see to the methodical increase in scale of the number of Xinjiang's minority masses who will go to the interior (neidi 内地) to receive education, find employment and settle, and in this way advance the deepened understanding and feelings of everyone of every ethnicity in their shared lives, work and study. ${ }^{43}$

The contradictions in this summary of his remarks, between maintaining the existing system of separation of ethnic groups (as under current policy) on the one hand, and fostering greater intermingling and mixed settlement (as proposed in the DMZ) on the other, is striking, but even more remarkable is his quotation of $\mathrm{Hu}$ Angang's formulation of the "three inters". With this unmistakable reference to the principal author of the second-generation proposal, Xi sent a clear signal that, at least in Xinjiang, he might like to put in place a set of policies that are closer in spirit to an assimilationist model of ethnic relations. If this were to happen-and the comment made in August 2014 by the Xinjiang Party Secretary that preferential family planning policies for Uyghurs should be terminated, suggests that the situation is continuing to develop ${ }^{44}$-it would mark a sea change in the way in which the Party leadership deals with the non-Han. Furthermore, as I explain below, it would seem to require a rewriting of the 1982 Constitution.

\section{SECOND-GENERATION ETHNIC POLICY AS AN OPEN DEBATE}

It is notable that a public debate over the DMZ is happening at all: this would seem to indicate a broadening of a trend remarked on by others with respect to

43. Xinhua News Agency, "Xi Jinping: kuoda Xinjiang shaoshu minzu dao neidi juzhe guimo” (Xi Jinping: Expand the Scale of Moving Xinjiang Ethnic Minorities to Live in China Proper) (29 May 2014), http://news .xinhuanet.com/politics/2014-05/29/c_1110926294.htm, accessed 31 July 2014.

44. Zhang Chunxian, "Fenli puxie Xinjiang shehui wending he changjiu zhian xin pianzhang" (Do One's Best to Write a New Chapter of Social Stability and Lasting Security in Xinjiang), Qiushi (Seeking Truth) (1 August 2014), http://theory.people.com.cn/n/2014/0801/c83846-25385969.html, accessed 7 August 2014. 
the "ecology" of policy formation in the PRC..$^{45}$ As is well known, policy-making in China remains very much a top-down process; participation is restricted to government bureaucrats and well-connected élites whose status (political, economic and intellectual) affords them entry to the leadership circles where decisions are made about the national agenda. ${ }^{46}$ Policy discussions typically do not happen openly, nor do they involve a wide swath of the public, as is often the case in other countries, where television pundits, radio hosts, bloggers, newspaper columnists and letter-writers all feel free to weigh in on any and all issues, from the local to the national and international; ${ }^{47}$ hence the dearth of sustained public debates (as opposed to isolated protests) over the pros and cons of many issues of primary concern to the nation.

In the past decade or so, however, vigorous discussions have begun to emerge in a few areas, including social justice, ${ }^{48}$ health care, ${ }^{49}$ energy policy, ${ }^{50}$ foreign affairs, ${ }^{51}$ family planning ${ }^{52}$ and governance. ${ }^{53}$ The dominant voices in these conversations belong to members of think tanks, university academics and government officials; and while the exchange of views is often handled via confidential reports and speeches at workshops, closed conferences or at meetings behind the scenes, more and more often these debates make their way into the media, and public opinion in one form or another is brought into the discussion. ${ }^{54}$ The debate over the DMZ is another example.

45. On the "alchemy" of making foreign policy, see Bonnie Glaser and Evan Medeiros, "The Changing Ecology of Foreign Policy Decision-Making in China: The Ascension and Demise of the Theory of 'Peaceful Rise", The China Quarterly, No. 190 (June 2007), pp. 291-310.

46. The best-known model for understanding post-1979 policy planning in the PRC is probably Michel Oksenberg and Kenneth Lieberthal's "fragmentary authoritarianism". This model is challenged by Shaoguang Wang, who argues that "today the public is not an ignored bystander but is seriously involved in the agendasetting process ... there is an impressive congruence between the priorities of the public and the priorities of the Chinese government". See Shaoguang Wang, "Changing Models of China's Policy Agenda Setting", Modern China, Vol. 34, No. 1 (January 2008), p. 81.

47. Such open contestation of issues by voices that are markedly unofficial is characteristic of what Shaoguang Wang calls the "reach-out" and "outside access" models of policy-planning, and is, in his view, "by no means common". Shaoguang Wang, "Changing Models", p. 68.

48. Yingjie Guo, "Discourses of Justice and Class: Impact of China's Intellectual Elites on Social Policy", in Xiaowei Zang and Chien-wen Kou (eds), Elites and Governance in China (London: Routledge, 2013), pp. 12-33.

49. Prompted by the SARS crisis of 2003. See Shaoguang Wang, "Changing Models", pp. 68-69.

50. Shaoguang Wang, "Changing Models", p. 70.

51. James Reilly, Strong Society, Smart State: The Rise of Public Opinion in China's Japan Policy (New York: Columbia University Press, 2012).

52. Cf. "Debate: Family Planning", China Daily (21 March 2011), http://www.chinadaily.com.cn/cndy /2011-03/21/content_12199686.htm, accessed 7 August 2014.

53. Yingjie Guo, "The Role of Intellectual Elites in China's Political Reform: The Discourse of Governance", in Xiaowei Zang and Chien-wen Kou (eds), Elites and Governance in China, pp. 34-53.

54. On the relationship between "think tanks" and the government, see Quansheng Zhao, "Moving Between the Inner Circle and the Outer Circle: Think Tanks and Policy Making in China", in Xiaowei Zang and Chien-wen Kou (eds), Elites and Governance in China, pp. 54-72. 
The stakes in this debate are very high. In proposing a new model, Ma is implicitly challenging the orthodoxy of the past 20-odd years, set in place by his own teacher, London-trained anthropologist Fei Xiaotong (费孝通)—although, depending on how one reads Fei's work, it could also be argued that he is in fact striving to realize Fei's ideal, frequently cited, that held, "We are among you, and you are among us" (ni zhong you wo, wo zhong you ni 你中有我, 我中有你). Late in his career, Fei detailed the theory of a "unified polyethnic national configuration” (tongyi de duominzu guojia geju 统一的多民族国家格局) which, by openly recognizing the ethnic diversity of the country's people, would provide the basis for a stable system representing the political will of the entire population of the PRC. ${ }^{55}$ Fei was careful to use the expression Zhonghua minzu, literally, "peoples of the Central Florescence". This term, obviously very awkward in English, was a modern neologism, invented by Liang Qichao (梁启超) in the late Qing as a deliberately ambiguous formulation aimed at bridging the space between the Han people and all the other ethnic groups living within the borders of the empire. ${ }^{56}$ It has since come to be used widely wherever a comprehensive term is needed to refer to people who identify culturally as Chinese, regardless of citizenship or political persuasion. In questioning this orthodoxy, or at least questioning how the unity that Fei envisioned is to be realized, Ma has put his finger precisely on the central problem that Fei's theory left unexplained, which is that hardly anyone in China-not now, and not at any time in the $20^{\text {th }}$ century-actually identifies himself or herself as a member of the Zhonghua minzu. ${ }^{57}$

Moreover, nowhere in the Chinese Constitution does it say anything about the Zhonghua minzu or the relationship between the Zhonghua minzu and the Zhonghua renmin gongheguo (People's Republic of China 中华人民共和国). Alternative solutions are needed to the basic problem that Fei tried to tackle-how to incorporate non-Han people into what is, for all intents and purposes, a Han nation-state.

55. Fei Xiaotong, "Zhonghua minzu de duoyuan yiti geju" (The Unified Polyethnic National Configuration of the Chinese People), Beijing daxue xuebao, Vol. 4 (1989), pp. 1-19. This was originally given as the Tanner Lecture at the Chinese University of Hong Kong in December 1988 under the simpler title, "Duoyuan yiti geju”.

56. James Leibold, Reconfiguring Chinese Nationalism, p. 32. Ironically, Liang also invented the term guozu, discussed above.

57. Naturally, it is impossible to state categorically that no one self-identifies as such. However, for a number of years at public talks I have been asking Chinese audiences, "Nin shi shenma minzu? Nin shi Zhonghua minzu ren ma?" (What ethnicity are you? Are you a Zhonghua minzu person?). I have yet to receive an affirmative answer. A Google search for the exact phrase, "Wo shi Zhonghua minzu ren" (I am a Zhonghua minzu person) turns up very, very few hits, most of them netizens aiming to persuade Chinese in Taiwan that they, too, belong to the Zhonghua minzu, not the Zhonghua minguo. The Zhonghua minzu label would only gain real validity if non-Han were to adopt it as a mode of self-identification. This has not happened, at least not for people living within the borders of the PRC. 
It is impossible to know for certain why it has been decided that it is advisable to make this debate an open one, or who has made this decision. It does seem, however, that the people at the middle and upper levels of the leadership are following this debate, and that opinions remain divided. Meanwhile, the disputation continues.

\section{TAKING A GLOBAL PERSPECTIVE: ETHNICITY AND INDIGENEITY}

The second aspect of the debate over the DMZ that deserves our attention has to do with terminology and the framing of the question over "ethnicity" and nonHan identity generally. The question has received considerable attention from Ma Rong and many others, and is closely linked to Ma's stated desire to depoliticize the discussions around the situation of non-Han peoples in China. The debate has proceeded along two tracks. The first track, which has more or less concluded, focused on discussions over the proper terms in Chinese for thinking about ethnicity. The second has to do with the question of the comparability of China's ethnic situation and the search for proper analogies, particularly as concerns native peoples.

Chinese-language terminology in discussions about identity is relatively new and in many cases confusing, since it almost never lines up neatly with terms in English or other Western languages. China has its own long history of identity discourse but, since the West is where the modern academic discourse of identity began and where the concepts central to its analysis are rooted, it is important to try to stabilize the relation between Chinese terms and terms in other languages. This has proved very difficult when it comes to the word minzu. Like many other key social science terms used in Chinese, minzu began as a Japanese neologism, minzoku, invented to translate the German word Volk. As most readers will be aware, the word minzu is susceptible of a wide range of translations and interpretations, but these may be broken down into three main sets of meaning: "nation", "ethnic group/ethnos" and "minority group". ${ }^{58}$ Confusion among these meanings of minzu has led to endemic misunderstanding.

Challenges to the meanings of minzu have led to a broad consensus across Chinese academia that minzu is no longer suited to describe what in English is called "ethnicity". While there remains considerable discussion of this subject in the literature, the majority of Chinese scholars now seem to agree that minzu

58. On this, there seems broad agreement among Chinese and Western scholars. See Zhou Chuanbin, "Lun Zhongguo tese de minzu gainian" (Ethnicity with Chinese Characteristics), Guangxi minzu yanjiu (Study of Ethnics in Guangxi), Vol. 4 (2003), pp. 19-30, and Hao Rui [Stevan Harrell], “'Minzu' gainian fanyizhong de nanti” (The Difficulty in Translating the Concept of Minzu), Minzu shehuixue yanjiu tongxun, Vol. 75 (November 2010), pp. 36-37. 
should be reserved for ideas such as "nation" or "people" and that, for the more anthropologically inflected notion of ethnicity, it is better to use the word zuqun. ${ }^{59}$ If this consensus holds, this would seem to be a step forward in the establishment of a common vocabulary that will permit a more effective exchange of ideas and allow for a clearer distinction between ideas that are primarily political and those that are primarily anthropological or sociological.

In practical terms, the effects of the emergence of the term zuqun and the decline of minzu as "nationality" are most obvious in the English translation of the names of institutes and journals. For instance, Zhongyang minzu daxue (中央民族大学), which used to be the Central Minorities Institute, and later the Central University for Nationalities, is now the "Minzu University of China"as if "Minzu" meant anything in English. ${ }^{60}$ Journals and newspapers published in China with minzu in the title switched from "nationality" to "ethnic" in the early 2000s, but more recently have changed again, leaving the word simply as minzu. While for some this seems to be a sort of solution, for those in search of mutual understanding it seems to be something of a surrender. ${ }^{61}$

59. It is worth pointing out that this terminological shift in itself is already a major concession to international norms. A 2001 editorial in Renmin ribao argued that zuqun was a Western term totally unsuited to China's "unique national conditions" (Sha-li-ke, “'Zuqun' yu 'minzu' de guoji duihua” [The International Dialogue Between Zuqun and Minzu], Renmin ribao [People’s Daily] [2 November 2001]). There is a superb short history of these different etymologies and terminological usages in Zhou Chuanbin, "Lun Zhongguo tese de minzu gainian". Other useful discussions of the term zuqun include Hao Shiyuan, "Ethnos (minzu) he Ethnic Group (zuqun) de zaoqi hanyi yu yingyong" (The Early Meanings and Applications of "Ethnos" and "Ethnic Group"), Minzu yanjiu (Ethno-National Studies), Vol. 4 (2002), pp. 1-11; Wang Dongming, "Guanyu minzu yu zuqun gainian zhi zheng de zongshu" (A General Account of the Controversy Between the Concepts Minzu and Zuqun), Guangxi minzu xueyuan xuebao (Journal of Guangxi University for Nationalities), Vol. 27, No. 2 (March 2005), pp. 89-97; Chen Xinlin, "Zuqun lilun yu Zhongguo de minzu yanjiu" (Theories of Ethnicity and Research on Chinese Minorities), Guizhou minzu yanjiu (Guizhou Ethnic Studies), Vol. 6 (2005), pp. 1-5; Jian Zhixiang, “'Zuqun’: shehui qunti yanjiu de jichuxing gainian gongju” (Zuqun: A Fundamental Conceptual Tool in Research on Social Groups), Beijing daxue xuebao, Vol. 44, No. 5 (2007), pp. 138-47; and Qi Jinyu, "Zuqun rentong yu zuqunxing yanjiu: jianlun dui Zhongguo minzu wenti yanjiu de yiyi” (Ethnic Identity and Research on Ethnicity: Its Significance for Research on China's Ethnic Issues), Qinghai minzu yanjiu (Nationalities Research in Qinghai), Vol. 21, No. 1 (2010), pp. 20-27. A very useful survey of the literature going back to $c a$. 1999, with a complete bibliography, is Jin Binggao, Bi Yueguang and Han Yanwei, "Minzu yu zuqun: shi gainian de hubu haishi dianfu?" (Minzu and Zuqun: Concepts that Supplement or Overthrow?), Heilongjiang minzu congkan (Heilongjiang Nationality Series), Vol. 127, No. 2 (2012), pp. 4-15.

60. Though it should be said that, as Stevan Harrell has pointed out, "translating" minzu as "minzu" in English has at least the virtue of avoiding creating equivalencies where none exist.

61. For a recent discussion of these changes, see Hu Yan, "Yetan sheji minzu guanxi de Zhong-Yingwen cihui" (More on Chinese-English Vocabulary Pertaining to Ethnic Relations), Xuexi shibao, Vol. 6, No. 5 (24 May 2011), http://theory.gmw.cn/2011-05/24/content_1998525_2.htm, accessed 7 August 2014. Recognizing that there is not a single word that can translate minzu in every context, Hu instead advocates the use of minzu in all English-language writing, which he says is a way of resisting the "hegemony of Western languages" in international discourse. In other words, minzu in China is not only a difficult concept but a unique one, and we may as well not even try to translate it. 
The rise of zuqun is about more than the wish for greater precision in specialized academic language or a growing awareness among Chinese academics (and government officials, for that matter) of the importance of the words used in English to translate Chinese terms and names. It also has to do with substituting a different vocabulary in both English and Chinese for the prevailing discourse of minzu. The reasons are not hard to understand. In Chinese, using a polyvalent word such as minzu to talk about the Zhonghua minzu, the Han minzu (汉民族), Huaxia minzu (华夏民族), Menggu minzu (蒙古民族), shaoshu minzu, minzu wenhua (民族文化), minzu yuyan (民族语言) and so forth implies a kind of equivalence between all these meanings of minzu. Add to this countless routine references to minzu guojia (民族国家), minzu zhuyi (民族主义), minzu yingxiong (民族英雄) or minzu tuanjie (民族团结), and what results is an imputed political consciousness following upon the simple fact of minzu.

The problem is perhaps even more evident in English. Is a minzu a "nation", or is it a "nationality", a "race", an "ethnic group" or a "minority group"? However it is interpreted, there is no getting away from the fact that, just as within the English word "nationality" is the root word "nation", so within the Chinese expression shaoshu minzu there is the word minzu. Both terms are prone to be applied in political contexts, and may be thought to embody an inchoate nationalism or national consciousness that could one day be called into existence. Before the break-up of the USSR this was never an issue, but after 1991 many observers have come to fear a similar outcome in the PRC. One reason to get rid of minzu in discourse over non-Han peoples in China, then, is to avoid a situation in which different minzu all make a claim for their own minzu guojia, as happened after the fall of the Soviet Union. ${ }^{62}$ The only minzu that is entitled to its own minzu guojia is the Zhonghua minzu. Under such circumstances, everyone is better off if the others are called by some name other than minzu.

If they are not minzu, then, what are they? This is where Western academic discourse on ethnicity has come in handy, since it carries none of the same baggage as "nation" and would appear to create a more neutral discursive space. Like the English word ethnicity (which is only about 60 years old ${ }^{63}$ ), the word zuqun is a neologism, entering common usage only in the last two decades. It is not clear whether zuqun will catch on at official levels within China as it has in Taiwan but, as already mentioned, it offers a theoretical vocabulary that makes it appealing to many academic writers seeking a solution to the eternal confusion surrounding minzu.

62. On both sides of the debate, Chinese authors themselves refer to the fate of Yugoslavia and the fall of the USSR as playing a role in instigating a rethinking of ethnic policies in the PRC. See Hao Shiyuan, "Jianchi minzu quyu zizhi zhidu”, p. 66, and Zhu Weiqun, "Guanyu dangqian”, p. 15.

63. Its first appearance in the Oxford English Dictionary was in 1953. My thanks to Stevan Harrell for drawing my attention to this. 
The move away from minzu-nationality, and the discovery of zuqun-ethnicity, is one thread in the current debate over the DMZ. Another result of employing zuqun as a conscious equivalent of "ethnicity" is that it suggests that the ethnic situation in China is not sui generis, but that, in its broad outlines, it is in fact comparable to ethnic situations elsewhere in the world. Some scholars (most notably Ma Rong) are in effect arguing that China's ethnic problems, even if they are special, are not unique: that China actually shares a great deal with other countries (such as the United States) with polyethnic, "multicultural" societies, and can benefit from learning from their experience. ${ }^{64}$ China is not alone in having to reconcile the problem of modern national form with its considerably more complicated demographic realities. ${ }^{65}$

The question of finding suitable global analogies for understanding the Chinese situation thus constitutes a second important metanarrative in the DMZ discussion. While analysts of all stripes make frequent reference to ethnic policies in other parts of the world, few do so as often as Ma Rong. Having studied in the US, a country he visits often and knows well, Ma writes regularly of the need to approach ethnicity in China in the same way as it is approached in the United States. However, given his extensive familiarity with American society and with the literature on ethnicity, Ma's conviction that ethnicity can be dealt with purely as a matter of culture is surprising, on at least two counts. First, as he knows, ethnicity in the US is inherently political. To take the American case as an example of how to "depoliticize" ethnicity seems mistaken.

Moreover, his rationale for ending preferences for minorities draws on examples from the US, such as affirmative action. Ma aims to persuade readers that it is because of affirmative action that ethnic difference persists in the US and that, if affirmative action and other institutional mechanisms that acknowledge (some would say "reinforce") ethnic difference were abolished, ethnic difference would "naturally" fade away. ${ }^{66}$ Whether or not this is true (it is a question of no little controversy, to be sure), his critics have charged him with secretly wishing to do

64. The publicity for Xie Zhong's 2010 collected volume dedicated to discussion of Ma Rong's ideas drives this point home emphatically: "Chinese should absorb the valuable experience of their forefathers whose tradition for managing ethnic relations stretches over several thousand years. They should also learn from the strategies and experiences of the United States, India and the former Soviet Union in the management of their own racial and ethnic issues" (from an advertisement in Zhongguo minzubao, Vol. 3 [2010]), http://www.mzb .com.cn/html/Home/report/131403-1.htm, accessed 21 August 2014.

65. One must bear in mind that there is a substantial range of opinion as to whether China is in fact comparable to other countries or whether its national form is unique and peculiar to China alone. This latter position often tends toward the rejection of any application of contemporary Western social science theory to the analysis of Chinese society, politics or history-though it does not go so far as to advocate the rejection of all Western social science theory, since those arguing this position continue to embrace Marxism.

66. Ma Rong, Ethnic Relations in China (Beijing: China Tibetology Publishing, 2008), p. 100. 
away with ethnic difference in China altogether. ${ }^{67}$ The second surprising aspect of Ma's looking to the United States is that the US is primarily an immigrant society. The presence, not just of most minorities, but also of the majority population, is the result of migration from other parts of the world, whether voluntary or involuntary. Until now, this has been by no means the case in China (though even this is changing, as seen in the growing immigrant population in and around Guangzhou), and Ma has been criticized on this score as well. ${ }^{68}$

Unlike a number of Ma's critics, I do not want to suggest that Ma is wrong to look outside China for examples of other models for managing ethnic relations. ${ }^{69}$ I would suggest, however, that he and others have chosen the wrong analogies. If one is to look at societies globally, a far better analogy than that of "AfricanAmericans", "British Asians", "Français d’origine algérienne" or "Deutschtürken"all of whom represent immigrant or diasporic populations-would be that of native peoples in North America, Australia and New Zealand, together with any number of South American countries, such as Ecuador, Brazil and Peru. The situation of many of China's non-Han peoples, the vast majority of whom have been living in their homelands for many centuries and whose presence there long predates the arrival of people from the Central Plains (zhongyuan 中原), bears much more similarity to that of aboriginal peoples or "First Nations" around the world than to emigrant or diasporic populations such as Africans, Asians, Latin Americans and others living now in the US, Europe and elsewhere. ${ }^{70}$ The parallels on many levels (income/share of GDP, education, vital statistics, historical experience, cultural crisis) between Chinese minorities such as Tibetans, Uyghurs, Mongols, Kazakhs, Kirghiz, Bai, Yi, Miao and others with Native Americans,

67. Wang Xien, "Ye tan zai woguo minzu wenti de 'fansi' he 'shishi qiu shi': yu Ma Rong jiaoshou de jidian shangque" (More on the "Reflections" and "Seeking Truth from Facts" in the Domestic Debate on Ethnic Policy: A Few Points of Discussion with Professor Ma Rong), Xinan minzu daxue xuebao (Journal of Southwest University for Nationalities), Vol. 1 (2009), pp. 1-17; Hao Shiyuan, "Guoji jingyan de bijiao he jiejian bixu shishi qiu shi: lun dierdai minzu zhengce shuo zhi san” (In Making International Comparisons and Analogues, One Must Seek Truth from Facts: Three Points on the Second-Generation Ethnic Policy), Zhongguo minzubao (2 March 2012), p. 6; Hao Shiyuan, "Meiguo shi Zhongguo jiejue minze wenti de bangyang ma? - ping 'dierdai minzu zhengce' de 'guoji jingyan jiaoxun' shuo" (Is the US a Model for Solving China's Ethnic Problems? A Critique of the Notion of "Lessons of International Experience" in the "SecondGeneration Ethnic Policy"), Shijie minzu (Ethnic Groups of the World), Vol. 2 (2012), pp. 1-15.

68. Wang Xien, "Ye tan zai woguo minzu wenti"; Hao Shiyuan, "Meiguo shi Zhongguo jiejue minze wenti de bangyang ma?"; Hao Shiyuan, "Meiguo minzu zhengce bushi Zhongguo de bangyang” (America's Ethnic Policies Are Not a Model for China), Guizhou minzubao (Guizhou Nationality News) (16 July 2012), p. 2. Ma's responses to his critics may be found in Ma Rong, "Reflections on the Debate on China's Ethnic Policy: My Reform Proposals and Their Critics", Asian Ethnicity, Vol. 15, No. 2 (2014), pp. 237-46.

69. Hao Shiyuan, for instance, argues that China's "national conditions" mean that no realistic or useful comparisons with the ethnic policies of other countries are possible. See Hao Shiyuan, "Meiguo shi Zhongguo jiejue minze wenti de bangyang ma?".

70. The other obvious analogy to the Chinese case is that of India, and Ma Rong has discussed this in some places (for example, Ma Rong, "A New Perspective in Guiding Ethnic Relations"), but not in any depth. The value of the comparison is severely critiqued in Barry Sautman, "An India/US Model". 
Inuit, Aborigines and Torres Strait Islanders, and Maori are striking. ${ }^{71}$ All these groups (or significant majorities of their populations) continue to live on lands to which they have reasonably strong ancestral claims; in their encounter with the majority Other, all of them assume the status of "natives" vis-à-vis the representatives of a central (often formerly colonial or quasi-colonial) government from the outside; and all of them find themselves in positions of relative weakness as a result of an asymmetrical power structure, often the consequence of technological inferiority. ${ }^{72}$

Yet, with the significant exception of aboriginal peoples in Taiwan, ${ }^{73}$ it appears that there is no discussion anywhere in the Chinese-language literature of “aborigines”-variously called yuanzhumin (原住民), yuanjumin (原居民), xianzhumin (先住人) or tuzhuren (土著人)—in mainland China. ${ }^{74}$ If one searches scholarly articles, the only context in which the term "aborigine" is used is in discussions-usually by foreign anthropologists or sociologists-of native peoples in Canada or elsewhere, and never with any reference to China. ${ }^{75}$ My research has turned up only two exceptions. One is a short, one-page column published in 2007, titled “'Aboriginal Rights': The Question of Deep-Level Social Harmony”,

71. Not all of China's shaoshu minzu fall into this category; most notably, it is difficult to make the case that either Hui or Manchus are truly "aboriginal", since their wide population distribution today is manifestly the result of a long period of diaspora.

72. One might think that Han Chinese might be able to understand the mindset of its aboriginal nonHan peoples, since the Han themselves were relegated to a similar sort of position in the later $19^{\text {th }}$ and early $20^{\text {th }}$ century, when Europeans and Japanese arrived in China in large numbers, uninvited for the most part and backed by superior technology, and attempted in varying degrees to impose their own social, political, economic and cultural norms upon China's native population. If there is little such awareness, this is probably because so much of modern Chinese national identity is itself wrapped in a narrative of victimization, from which it is difficult to escape. See Jing Tsu, Failure, Nationalism, and Literature: The Making of Modern Chinese Identity, 1895-1937 (Stanford: Stanford University Press, 2005), and Zheng Wang, Never Forget National Humiliation: Historical Memory in Chinese Politics and Foreign Relations (New York: Columbia University Press, 2012).

73. For many Chinese speakers, yuanzhumin is simply another reference to non-Han groups in Taiwan. Thus, the Baidu entry for yuanzhumin is nearly entirely devoted to a description of the two main (imagined) Taiwan aboriginal groups, the so-called "Gaoshanzu" and "Pingpuzu". See http://baike.baidu.com/view /197643.htm, accessed 22 August 2014.

74. Of these terms, yuanzhumin (a loan word from Japanese) and yuanjumin would seem to come closest in meaning to the original word that it is meant to translate, "aborigine" (from Latin ab origine, "from the beginning"), meaning the original inhabitants of a place. Tuzhuren is the word most commonly used to translate "indigenous". One recent attempt to draw a distinction between these terms offers a detailed accounting of their use in Chinese academic writing, confirming its exclusive application to the ethnic situation in Taiwan; see Jiang Deshun, "Luebian 'tuzhu' yu 'yuanzhumin'” (A Rough Differentiation Between Tuzhu and Yuanzhumin), Shijie minzu, Vol. 6 (2012), pp. 7-12. Another recent article discusses the various theoretical definitions of these and other terms, but makes no effort to apply them to the PRC; see Ming Hao, "'Minzu' zizhi de lilun yu shijian" (The Theory and Practice of "Ethnic" Autonomy), Zhongyang minzu daxue xuebao (Journal of Minzu University of China), Vol. 41, No. 3 (2014), pp. 37-48.

75. A typical example (in which China is not mentioned) is Da-wei C. Huo-ke-si [David C. Hawkes], "Yuanzhumin: zizhi he zhengfujian guanxi" (Indigenous Peoples: Autonomy and Intergovernment Relations), Guoji shehui kexue zazhi (International Social Science Journal), Vol. 1 (2002), pp. 147-54. 
which has to do with rural land rights. ${ }^{76}$ The author's use of the term is not particularly relevant to the present discussion, except that it suggests that the word yuanzhumin is understood to refer to shaoshu minzu, even though it never appears in this way in any published discussions of ethnicity in China. ${ }^{77}$ The other exception is a pictorial album of the peoples of Hainan (like Taiwan, another semi-tropical island), titled Native Hainanese. ${ }^{78}$ This is also a false lead, however, since the Chinese title studiously avoids the word yuanzhumin, for reasons that will shortly become clear.

Given the similarities between the experience of many of China's ethnic minorities and that of other native peoples around the world, one cannot help but ask why the discussion in the PRC has failed to include any mention of aboriginal groups, even at a moment when debate is so free-ranging and outside models for managing ethnic relations are actively being sought. The reasons for this taboo are primarily political.

First, to use aboriginal discourse would be to risk potentially complicated associations with international norms on the rights of first-nation peoples. That is to say, if the government were to abandon the present shaoshu minzu paradigm and instead acknowledge that some non-Han peoples were in fact yuanzhumin, from the center's point of view it would open up a Pandora's Box of new problems. For instance, the PRC might feel pressure to comply with the UN Declaration on the Rights of Indigenous Peoples, ${ }^{79}$ and complaints from dissatisfied ethnic groups could be lodged with the UN Permanent Forum on Indigenous Issues. The most

\footnotetext{
76. In this essay, Tang Jun, a scholar of social policy at the Academy of Social Sciences, responds to the Party's (then) new slogan of a "harmonious society". Challenging the idea that "harmony" is a realistic political goal at all, Tang asserts that it makes more sense to focus on eliminating sources of disharmony in society, and his first example is "aboriginal rights", or yuanzhumin quanli. His use of the term yuanzhumin, however, refers to long-term residents of any place, in particular rural farmers, whose rights-especially land rights—-he argues, are consistently violated by the state. See Tang Jun, "'Yuanzhumin' quanli: shehui hexie de shengcengci wenti” (“Aboriginal Rights": The Question of Deep-Level Social Harmony), Shehui guancha (Social Observation), Vol. 1 (2007), p. 50.

77. 'In contemporary China, the neglect of the rights of 'aboriginal peoples' is perhaps a deeper reason for disharmony. The original meaning of 'aboriginal peoples' is 'indigenous', which in the great majority of circumstances refers to minority nationalities. But in this essay (because I cannot find a suitable word or concept in modern Chinese to represent the thing I want to describe), I tentatively borrow this term to refer to the 'local residents' who have lived in a locale for a long time, perhaps even for several generations" (Tang Jun, "'Yuanzhumin' quanli”).

78. Huang Yiming, Hainan xianzhumin (Native Hunanese) (Beijing: Zhongguo Tushu Chubanshe, 2012). See the announcement of the publication at http://www.hainan.gov.cn/hn/yw/shfz/kjwt/wt/201201/t20120130 _641442.html, accessed 7 August 2014.

79. The English version of the declaration is at http://www.un.org/esa/socdev/unpfii/documents/DRIPS _en.pdf, accessed 22 August 2014. The Chinese version of the declaration may be found at http://www.un.org /esa/socdev/unpfii/documents/DRIPS_zh.pdf, accessed 22 August 2014. The same document is at http:// indigenous.teldap.tw/resource/international/26-2010-01-26-08-16-23.html, accessed 22 August 2014.
} 
sensitive issue in this Declaration, though, has to do with land rights. Articles 25 and 26 of the UN Declaration state:

\section{Article 25}

Indigenous peoples have the right to maintain and strengthen their distinctive spiritual relationship with their traditionally owned or otherwise occupied and used lands, territories, waters and coastal seas and other resources and to uphold their responsibilities to future generations in this regard.

Article 26

1. Indigenous peoples have the right to the lands, territories and resources that they have traditionally owned, occupied or otherwise used or acquired.

2. Indigenous peoples have the right to own, use, develop and control the lands, territories and resources that they possess by reason of traditional ownership or other traditional occupation or use, as well as those which they have otherwise acquired.

3. States shall give legal recognition and protection to these lands, territories and resources. Such recognition shall be conducted with due respect to the customs, traditions and land tenure systems of the indigenous peoples concerned.

Doubtless it was resistance to the idea of UN authority over indigenous issues that caused the United States, Canada, Australia and New Zealand to be the only countries to vote against the Declaration in 2007. China, it should be pointed out, voted in favor, and as a signatory would therefore have the obligation to abide by the Declaration's principles, if it were to recognize the presence of indigenous peoples within its borders. So long as it does not admit to their existence, this particular aspect of the human rights issue can be kept at arm's length.

Second, the very notion of “indigeneity" (tuzhuxing 土著性) would appear to be at odds with the concept of China as a "unified polyethnic state". In response to early discussions at the UN in 2004, PRC spokesman Qin Xiaomei (秦晓梅) made the government's position clear:

Question: I would like to ask one last question: does China have any problems with indigenous peoples?

Qin: As I have already explained, the concept of "indigenous" is used relative to external colonizers. China is a unified, polyethnic state; looking at the process of Chinese history, China's 56 ethnic groups are all resident nationalities of China. Therefore, indigenous peoples of the sort found in other parts of the world do not exist in China. On this point, I would like to further point out that indigenous peoples and ethnic minorities are two different concepts. In some countries, there 
may be many ethnic minorities but not a single aborigine. This sort of situation is extremely common in many countries in Asia, Africa and Europe. ${ }^{80}$

In other words, China can have no "indigenous peoples" because it was never a colonizer, and "aborigines" can exist only where colonial power has brought them into being. This is not what the Declaration in fact says (its sole reference to colonialism is in a passage referring to the "historic injustices as a result of, inter alia, their colonization and dispossession"), but it is a definition that, from the point of view of the center, fits conveniently within the Chinese context. This is because, despite recent discussions over the nature of the Qing empire raised by the "New Qing History", the overwhelming consensus among Chinese scholars is that the expansion of the Manchu state into Inner Asia in the $17^{\text {th }}$ and $18^{\text {th }}$ centuries was a project of "grand unification" (dayitong 大一统), not a process of conquest and colonization. One might want to ask whether "grand unification" would accurately represent the view of a Dzungar refugee in 1759, but that is a different question. ${ }^{81}$

The discussion on indigeneity may slowly be changing, however. Recently, one Chinese scholar has called attention to the limitations of this restricted understanding of the meaning of "indigenous" or "aboriginal"; without suggesting that China in fact does have "indigenous peoples", he has taken the bold step of pointing out that there are many discursive parallels between the words and concepts associated with indigeneity and those associated with the Chinese word tuzhu. ${ }^{82}$ Ma Rong has also joined the discussion, if hesitantly. In a two-part article published in 2013-14, Ma offers an exhaustive account of the recent history of the international movement to protect the rights of indigenous peoples, and details the application of the term "indigenous" (tuzhu) in studies of Taiwanese aborigines; nowhere does he mention the term with reference to China itself. Only at the very end of the article does Ma tip his hand:

80. See Ministry of Foreign Affairs, "Lianheguo diantai jizhe zhuanfang lianheguo tuzhuren changshe luntan Zhongguo zhuanjia Qin Xiaomei" (United Nations Television Journalist Interviews Qin Xiaomei, Chinese Representative to the Permanent UN Forum on Indigenous Issues) (24 May 2004), http://www.fmprc .gov.cn/chn/pds/gjhdq/gjhdqzz/lhg/zwbd/t437637.htm, accessed 3 August 2014. Qin was then professor of International Relations at Peking University.

81. To describe the historiographical background in detail would take us too far afield. One place to start is Liu Fengyun et al. (eds), Qingdai zhengzhi yu guojia rentong (Qing Politics and National Identity) (Beijing: Social Science Academic Press, 2012); also Ding Yizhuang and Ou Lide [Mark Elliott], "Ershiyishiji ruhe shuxie Zhongguo lishi: 'Xin Qingshi' yanjiu de yingxiang yu huiying" (Writing Chinese History in the $21^{\text {st }}$ Century: The Influence and Response to the "New Qing History"), in Peng Wei (ed.), Lishixue pinglun (Critical Historical Review), Vol. 1 (2013), pp. 116-46.

82. See Fu Haihong, "Cong 'manyi' dao 'yuanzhumin': Hanyu wenxianzhong de 'tuzhu' bianxi”" (From "Barbarians" to "Indigenes": An Analysis of the Word Tuzhu in Chinese-Language Sources), Beifang minzu daxue xuebao (Journal of the Second Northwest University for Nationalities), Vol. 104, No. 2 (2012), p. 124. 
What, after all, is the ultimate point of dividing social groups up so that there are clear boundaries between different "ethnic" or "indigenous" groups? Is it in the hope of maintaining a pluralistic structure of national identity and treatment of citizens that will last forever? Or is it in the hope of advancing the cultural acceptance of minority groups (indigenous peoples, minority ethnicities) into the overall cultural structure of society at large, of making them a constitutive part of the social whole of a country, and at the same time of advancing the acceptance of individual members of minority groups into the overall process of modernizing the social structure, and ensuring that they have the same ability to compete and the capacity for growth, that they have an absolutely equal status before the law, that they enjoy the same self-respect and self-confidence, and that they can equally share in the same benefits of social and economic development along with the members of other ethnic groups? I believe that this latter approach is the one more worth considering. Whether it has to do with the problem of "minority nationalities" in mainland China or "indigenous peoples" in Taiwan, perhaps these can both be discussed along these same lines. Both in mainland China and in Taiwan, discussion around these issues and investigation of the future path of development for minority ethnicities are [activities] entirely suited to meet the present objective requirements for the development of these groups within society at large and the development of their internal relations. ${ }^{83}$

Tentative as it is, this may still be seen as pushing the debate on ethnic policy in China further in the direction of global categories such as indigeneity, and away from "unique conditions".

For the moment, though, the formal position remains that China has no indigenes, no first-nation peoples, and therefore no first-nation problem, a stance recently restated in the pages of Zhongguo minzubao in a brief editorial by Ming Hao, whose part in these debates has been noted earlier. To reinforce his point that policies aimed at reducing ethnic difference and promote assimilationa reference to Ma Rong and the DMZ issue-are at odds with international trends, Ming (somewhat surprisingly) makes a nod in the direction of the UN Declaration on the Rights of Indigenous Peoples and notes China's approval of the Declaration. He then adds: "Although China emphasized that 'all the 56 ethnic groups in China, including the Han, are China's heritage-resident ethnicities (Zhongguo de shiju minzu 中国的世居民族)', China has no 'indigenous persons (tuzhuren 土著人) problem'”. Ming Hao's careful use of quoted language, with its tenuous (not to say tendentious) distinction between "heritage-resident ethnicities" and "indigenes", reveals little about what he really thinks, but much about

83. Ma Rong, "Minzu yanjiuzhong de yuanzhumin wenti (xia)" (The Issue of Indigenes in Ethnic Research, Part Two), Xinan minzu daxue xuebao, Vol. 1 (2014), p. 23. 
how far official discourse will go to prevent the discourse of indigeneity from taking root in the PRC. ${ }^{84}$

\section{CONCLUSION}

As is well known, the principles and rights in the UN Declaration are only irregularly enforced by any member of the UN, and it is unclear whether, in the admittedly unlikely event that there was a decision to acknowledge shaoshu minzu as tuzhuren, this would change very much. Still, if China were to amend its position on the definition of "indigenous peoples", it could raise expectations of other changes to follow. This leads to a third reason that, in the present debate, we find no comparisons of China's non-Han minorities with any of the world's aboriginal peoples. If the solution to the present crisis on the country's ethnic frontiers is seen to depend upon "depoliticization", then a turn to tuzhuxing does not really offer an easy solution. Getting rid of first-generation ethnic policies borrowed in some fashion from the USSR and moving to a second-generation policy, not like those proposed by Ma Rong or by the two Hus but based on principles contained in the UN Declaration on the Rights of Indigenous Peoples, would simply substitute one system of self-rule for another. Not only would ethnicity, if paired with indigeneity, remain a political issue, but it would be tied even more explicitly to land claims. This runs contrary to the entire goal of the current discussion of second-generation policy, which, by de-emphasizing the importance attached by the state to ethnic identity, aims to reduce the tension implicit in discussions over Tibet and Xinjiang, a tension that in the end amounts to insecurity over national borders. At the heart of depoliticization ( $q u$ zhengzhihua) lies the idea of deterritorialization (qu lingtuhua 去领土化). Bringing "aborigines" to the conference table would bring that connection to the surface, and make it impossible to de-link ethnic identity and territorial claims, but it would be both analytically more sound and politically more likely to achieve a long-term solution to present problems.

From this review of the debate over ethnic policy, one takes away two considerations. The first is that it is beneficial to have an open debate on ethnic politics in China which includes a comparative perspective and a reference to ethnicity in a variety of world contexts, because it permits a fuller exploration of different angles of the problem which would otherwise remain hidden. For instance, a global perspective suggests that it may not matter much whether or not the state gives advantages to people because of their ethnic background, whether one's

\footnotetext{
84. Ming Hao, “Tonghua, guoji shehui shuo bu!” (The International Community Says No! To Assimilation), Zhongguo minzubao (2 March 2012), p. 6. Shiju minzu is the term conventionally used to describe the eponymous people of a given autonomous region or zone who for generations have been considered to be inhabitants of the territory.
} 
ethnicity is officially confirmed on an identity card, or whether there exist legal frameworks that hypothetically allow "ethnics" (minzu) to regulate their own affairs and maintain their own language and culture. In any case, removing those elements of current ethnic policy as part of a program to emphasize the importance of culture over politics in the constitution of ethnic groups is unlikely to result in any attenuation of ethnic identity.

This conclusion leads to the other main lesson, which is that it is pointless to imagine that the question of ethnic identity and ethnic relations in China-or anywhere-can truly be depoliticized. Whether they are called shaoshu minzu or zuqun, a significant proportion of China's non-Han peoples, like many of China's Han population, will continue to see themselves as living in a country that deprives ordinary people of basic rights and freedoms. In other words, the predicament of today's non-Han peoples cannot be dealt with in isolation, but must be seen within the context of the larger political system, and within a new context in which it is not the immediate creation of national unity, but its long-term maintenance, that serves as the overarching guide to policy decisions. Meanwhile, as the violence on China's Inner Asian frontiers continues to grow, the debate will continue to gain in urgency and importance for Han and non-Han alike. 